REVIEW ARTICLE

\title{
One Conservation: the integrated view of biodiversity conservation
}

\author{
Cristiane Schilbach Pizzutto ${ }^{1,2}$ (D) , Helen Colbachini ${ }^{3}$ (D), Pedro Nacib Jorge-Neto ${ }^{1,2 \star}$ (D) \\ ${ }^{1}$ Faculdade de Medicina Veterinária e Zootecnia, Universidade de São Paulo, São Paulo, SP, Brasil \\ ${ }^{2}$ Instituto Reprocon, Campo Grande, MS, Brasil \\ ${ }^{3}$ Aquário de São Paulo, São Paulo, SP, Brasil
}

How to cite: Pizzutto CS, Colbachini H, Jorge-Neto PN. One Conservation: the integrated view of biodiversity conservation. Anim Reprod. 2021;18(2):e20210024. https://doi.org/10.1590/1984-3143-AR2021-0024

\begin{abstract}
The current global situation requires urgent decision-making to reverse processes of mass extinction of thousands of species. As a way of showing the importance of joint actions in this process, we aim to present the concept of One Conservation as a new proposal for the integration of sustainability, in situ and ex situ conservation for the restoration of ecosystems. According to the United Nations, we are beginning the decade of ecosystem restoration and in association with the International Union for Conservation of Nature guidelines, we can join efforts in the conservation of the planet. The survival of many species of wild animals depends on the management of populations currently maintained in ex situ conditions (under human care). To facilitate the exchange of genetic material between in situ and ex situ populations, reproductive biotechniques have become a great tool, making it possible to restore species in their natural environments. For effective conservation to occur, there must be an integrated view of the problem as a whole, and action for solutions must take place jointly by different spheres of society. Even more, conservation must be carried out by the public sector, the private sector, the third sector, and not less importantly, the agricultural sector. Therefore, One Conservation is defined as an interconnection between ex situ and in situ conservation plans, anthropic actions in the environment, and research in different areas that encompass conservation.
\end{abstract}

Keywords: in situ; ex situ; sustainability; wildlife; reproduction

\section{Introduction}

The human species, despite considered very young compared to other animal species (Gershwin, 2016), is endowed with complex intellectual characteristics and abilities (Gabora and Russon, 2011). Even so, humankind did not know how to work harmoniously with the mananimal-environment relationship. Unlike protectionism - which focuses on the integral protection of nature, without human interference -, conservationism contemplates saving the environment through sustainable and harmonious use of nature by humankind (Padua, 2006).

We are experiencing the sixth mass extinction of wildlife on Earth and human actions - such as deforestation, wildfire, mining, urbanization, habitat fragmentation, etc. - are rapidly changing the conservation status of several animal and plant species (Ceballos et al., 2015). Associated with all these problems, stochastic events have contributed to making animal populations smaller and isolated, leading them to fast and no return disappearing (vortex of extinction; Keller, 2002). Conservation actions are carried out around the world, reaching varying degrees of effectiveness. However, the lack of an integrated view between actions often limits their effectiveness.

*Corresponding author: pepovet@usp.br

Received: March 24, 2021. Accepted: May 10, 2021

Financial support: None.

Conflicts of interest: The authors declare no conflict of interest.

(c) (i) Copyright (c) The Author(s). This is an Open Access article distributed under the terms of the Creative Commons Attribution License, which permits unrestricted use, distribution, and reproduction in any medium, provided the original work is properly cited. 
Due to an urgent need to accelerate global actions focused on restoring degraded ecosystems (Waltham et al., 2020), the United Nations Decade on Ecosystem Restoration (2021 to 2030) was instituted to prevent, halt and reverse the degradation of ecosystems worldwide. It is a decisive moment for taking crucial decisions and establishing a partnership with all the stakeholders for the creation of conservation action strategies. Looking at this scenario, we aim to present the concept of One Conservation as a new proposal for the integration of sustainability, in situ and ex situ conservation for the restoration of ecosystems (Figure 1).

\section{Contextualizing the concept}

The perception of the integration between human and animal health began in the 19th century with Rudolf Virchow. It was achieved through the definition of the One Health concept as a worldwide strategy for the integration of human, animal, and environmental health through communication and collaboration between different professionals related to this area (Pinillos et al., 2015). Developing this concept, Pinillos et al. (2015) suggest a more complex approach, defining the One Welfare concept by recognizing the interconnections between animal welfare, human welfare, and environmental conservation.

Recognizing the urgency of creating a single global strategy to reverse social inequality and environmental degradation, the United Nations defined seventeen Sustainable Development Goals for its 2030 agenda (UN General Assembly, 2015). It also defined 2021-2030 as the Decade of Ecosystem Restoration.

The COVID-19 pandemic further highlighted the interrelationship between the health and well-being of man, animals, and the environment. And it is in this context that we suggest the creation of an even more comprehensive concept: The One Conservation concept, which encompasses One Health and One Welfare concepts and recognizes the interdependence of human species, animal species and conservation ecosystems.

Sustainability means guaranteeing the rights and well-being of humans without exhausting or diminishing the capacity of Earth's ecosystems to sustain life, or at the expense of the wellbeing of others (FAO, 2018). It is a multidimensional concept that encompasses the integrity of the environment, the well-being of society, economic resilience, and good governance. The integration of actions that facilitate the restoration of ecosystems is an emergency.

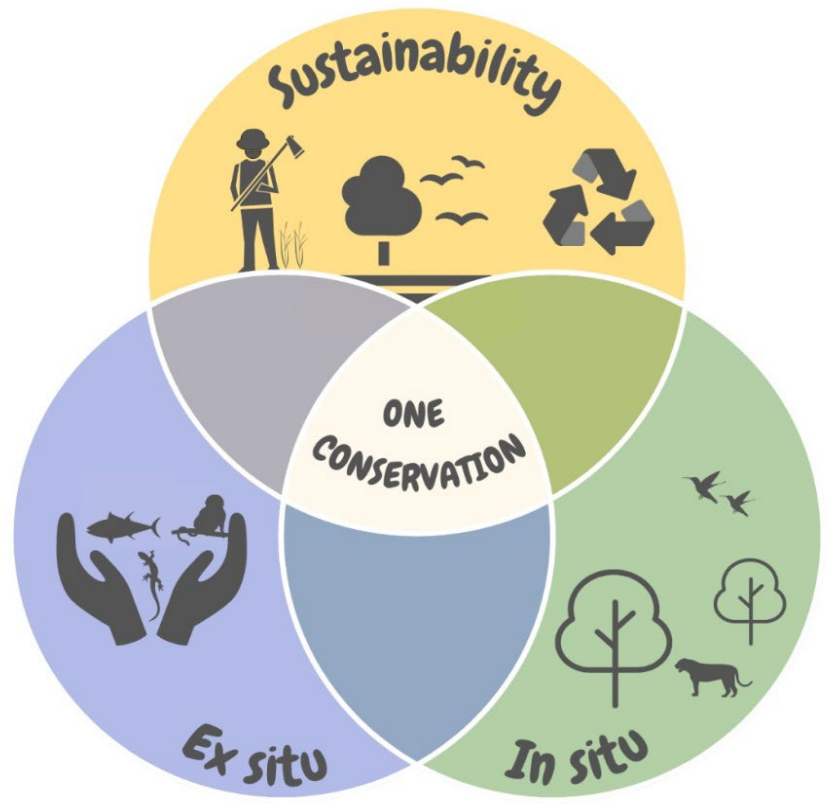

Figure 1. Venn Diagram - One Conservation is at the intersection of sustainability, ex situ, and in situ conservation. Illustrator: Carolina Schilbach Pizzutto 


\section{In Situ + Ex Situ}

Restoring populations is not an easy task and integrated actions between in situ and ex situ conservation are essential. Multidisciplinary joint actions, with public and private partnerships and from different segments of society must be performed. In situ conservation consists of strategies for the conservation of ecosystems and natural habitats and the maintenance and recovery of viable species by natural means. Ex situ conservation - under human care - focuses on the preservation and recovery of species through captive populations.

The ex situ maintenance of wild fauna is a target of criticism in several countries around the world, but currently this collection of animals under human care may be the only alternative for the survival of many species. The existence of a zoo or an aquarium is only justified by its ability to play its role within the four pillars established by Hediger (1950): conservation, research, education, and entertainment. Likewise, in situ conservation depends primarily on understanding and eliminating the factors of decline in wild populations. Thus, in situ conservation is not efficient when the species is below the minimum viable population. The synergism of ex situ and in situ actions reinforces not only the conservation pillar but also the need for the existence of these institutions.

Conservation, whether in situ or ex situ, involves maintaining minimum viable populations. A minimum viable population is the smallest population size with a high probability - $90 \%$ or more - of persisting for the next 100 years (Shaffer, 1990, 1981). Reed et al. (2003) estimated that the average minimum viable adult population size for most free-living vertebrate species is 7,000 individuals. In captivity, this number varies between 500 and 1,000 animals (Frankham et al., 2014; García-Dorado, 2015). Therefore, the IUCN guidelines (IUCN/SSC, 2014) include an insurance population among the strategies for an ex situ conservation program.

Often the only alternative for the survival of endangered species is the adoption of integrated ex situ conservation strategies for zoos, aquaria, and scientific breeding centers. At the same time, fundamental research in understanding the diversity of characteristics not only of these species but of practically the entire animal kingdom occurs in these institutions. For Pizzutto (2020), many of these characteristics come from the mechanisms involved in the regulation of the various physiological and behavioral models that have evolved from different adaptation strategies, as a result of selective pressures exerted by the modified environment or not.

When we manage wild animals intending to provide positive experiences for them within the domains of health, nutrition, environment, and behavioral interactions, we seek more than an adaptation to their environment, but that they thrive as a species and reach their level of ideal well-being, within the fifth domain - the mental. For Mellor et al. (2020), the effects in the fifth domain are generated by the brain processing of external stimuli from sensory inputs that allow animals to interact with their environments, achieving or not achieving their selected objectives. Behavioral interactions state the positive and/or negative emotions experienced by animals and will dictate the condition of well-being.

Everything reinforces how much conservation depends on well-being. Ensuring physical, mental, and emotional health to the animals are ways to guarantee a good aptitude for a species so that it can thrive, becoming able and viable in population management programs. A species kept ex situ fit and viable is a big step towards partnering with in situ. If these populations kept under human care can carry out the genetic exchange with free-living species and vice versa, zoos, aquaria, and scientific breeding centers will be exercising their role as a metapopulation and enabling an increase in genetic variability.

The view that in situ conservation actions should be prioritized before ex situ is outdated and obsolete. Both are equally important, and the One Conservation concept proposes that they should be conducted in an integrated way. The argument that ex situ conservation is expensive is limited way, as it disregards that private corporations, through zoos, aquaria, and scientific breeding centers, are extremely important players in the conservation milieu and invest and pay for ex situ actions. Equally, in situ conservation needs to be conducted realistically, based on facts. Conducting it only with optimism can result in the extinction of species or populations in certain areas or biomes by not sticking to the facts and 
procrastinating effective actions. Therefore, waiting passively for further studies may harm even more species in a critical conservation situation.

\section{Reproductive biotechnology for One Conservation}

The genetic exchange between in situ and ex situ populations can be facilitated by reproductive biotechnologies, such as artificial insemination, in vitro fertilization, embryo transfer, and even cloning and transgenics. According to Baldassarre et al. (2015), developing these biotechnologies would be critical for allowing their use as a tool for rebuilding balance in animal numbers for such endangered species.

The development of reproductive biotechnologies for wildlife species encompasses three main thematic: basic knowledge of the species (e.g., reproductive physiology, reproductive and copulatory behavior); male biotechniques (e.g., efficient semen collection and cryopreservation); and female biotechnologies (e.g., insemination techniques, ovum pick-up and in vitro embryo production).

Germplasm banks (biobanking) are being created all over the world to store biological material of various species maintained both in situ and ex situ. This can ensure the preservation of rare and endangered species in the future (Comizzoli, 2017). Associated with the studbook information and effective population management programs mentioned above, biobanking is a great ally of conservation. Since reproduction can be performed without the need to transport the animal, biobanking can safeguard species and allows directed breeding (decreasing the spread of diseases and injuries, eliminating genetic incompatibilities).

A great example is the Frozen Zoo, located at the Beckman Center for Conservation Research of the San Diego Zoo Wildlife Alliance. It is currently the largest and most diverse collection of germplasm in the world. It has the potential to produce offspring using reproductive biotechnologies and perhaps to rescue species like the northern white rhinoceros from the brink of extinction.

Strategies for the conservation of Brazilian fauna thru germplasm cryopreservation and storage in biobanks are being taken (Machado et al., 2016; Miranda et al., 2019; Praxedes et al., 2018a). Gametes of different species are being collected and cryopreserved (Araujo et al., 2020; Carelli et al., 2017; Silva et al., 2020b; Silva et al., 2019a, b) as well as somatic cells (Praxedes et al., 2018b) and fibroblasts and different tissues such as testicular (Silva et al., 2020a), ovarian (Campos et al., 2019b), skin from post-mortem animal (Machado et al., 2017; Santos et al., 2021), preantral follicles (Campos et al., 2019a) and even somatic feather follicle cell (Cardoso et al., 2020). Although these biotechnologies are extremely promising for the conservation of species, it is important to note that many of them have not yet been successful in free-living animals.

\section{One Conservation: the integrated view}

For effective conservation to occur, there must be an integrated view of the problem, and action for solutions must take place jointly by different spheres of society. Even more, conservation must be carried out by the public sector, the private sector, the third sector, and not less importantly, the agricultural sector. Society must be actively involved in conservation, from the housewife to the president of the country. Some of the professionals that work directly with conservation are animal scientists, biologists, botanists, conservation managers and planners, ecotourism guides, environmental education specialists, freshwater fishery biologists, landscape ecologists, marine biologists, park rangers, veterinarian, wildlife filmmaker, and photographer - the latter two being the great spokespersons for information and the state of nature conservation for society.

The insertion of farmers and ranchers in environmental care is essential for One Conservation, given the size of land owned by this category. Despite the intentions of the agribusiness sector, the support of conservation technicians is essential for taking positive action in sustainable and efficient rural production. Therefore, conservationists need to see 
agribusiness as an opportunity for sustainable conservation, not as a villain, and work together targeting One Conservation.

Despite the importance of all these actions being already known, the difficulty of integrating them in favor of conservation is still a major problem for the effectiveness of the different management plans. One solution would be to compile all information obtained from fauna projects on a single digital platform of technical and scientific knowledge and open access to scientific and civil society.

Another key point would be the maintenance of updated records of animals - through Zoological Information Management System, Studbooks, or other tools - maintained by institutions associated with Zoos and Aquaria Associations. These associations should also act as contact facilitators between different zoos and aquaria, as well as scientific breeding centers, research, and/or also in situ conservation institutions that know reproductive biotechnologies.

Registering and making these animals available to collaborate with One Conservation Programs should be mandatory and conditional for the certification process of zoos and their maintenance as associate members. These certifications would be an important step to ensure that populations kept in ex situ conditions are under the management of institutions that meet recognized protocols for animal care, and that these institutions are demonstrably committed to the conservation, increasing the trust of in situ research groups and working seamlessly with zoos and aquariums.

\section{Conclusions}

Synergism between different lines of research is essential for the conservation of any species and nothing is effective in isolation. In this way, different groups (e.g., behavior, in situ monitoring, environmental education, conflict resolution, reproduction, genetics, etc.) must work together for the same purpose: conservation. Conservation is essential to include environmental education actions for the coexistence and resolution of conflicts.

One Conservation is defined as an interconnection between ex situ and in situ conservation plans, anthropic actions on the environment (sustainability), and research in different areas that encompass conservation.

\section{References}

Araujo GR, Deco-Souza T, Bergo LCF, Silva LC, Morato RG, Jorge-Neto PN, Silva MCC, Macedo GG, Paula TAR. Field friendly method for wild feline semen cryopreservation. J Threat Taxa. 2020;12(5):1555764. http://dx.doi.org/10.11609/jott.5744.12.5.15557-15564.

Baldassarre H, Carelli JB, Requena LA, Rodrigues MG, Ferreira S, Salomão J, Jorge Neto PN. Efficient recovery of oocytes from "onça parda" (Puma Concolor) by laparoscopic ovum pick-up of gonadotropin-stimulated females. Anim Reprod. 2015;12(3):717-7.

Campos LB, Praxedes ÉCG, Saraiva MVA, Comizzoli P, Silva AR. Advances and challenges of using ovarian preantral follicles to develop biobanks of wild mammals. Biopreserv Biobank. 2019a;17(4):334-41. http://dx.doi.org/10.1089/bio.2018.0130. PMid:30896983.

Campos LB, da Silva AM, Praxedes ECG, Bezerra LGP, Gama Lins TLB, Menezes VG, de Matos MHT, Lima GL, Rodrigues APR, Silva AR. Vitrification of collared peccary ovarian tissue using open or closed systems and different intracellular cryoprotectants. Cryobiology. 2019b;91:77-83. http://dx.doi.org/10.1016/j.cryobiol.2019.10.193. PMid:31639331.

Cardoso CA, Motta LCB, Oliveira VC, Martins DS. Somatic feather follicle cell culture of the gallus domesticus species for creating a wild bird genetic resource bank. Anim Reprod. 2020;17(3):e20200044. http://dx.doi.org/10.1590/1984-3143-ar2020-0044. PMid:33029218.

Carelli JB, Jorge Neto PN, Requena LA, Rodrigues MG, Salomão JA Jr, Ferreira SAP, Pizzutto CS. In vitro fertilization of puma (Puma concolor) from vitrified oocytes and semen collected from epididymis of dead donor: case report. Rev Bras Reprodução Anim. 2017;41(1):364.

Ceballos G, Ehrlich PR, Barnosky AD, García A, Pringle RM, Palmer TM. Accelerated modern humaninduced species losses: entering the sixth mass extinction. Sci Adv. 2015;1(5):e1400253. http://dx.doi.org/10.1126/sciadv.1400253. PMid:26601195. 
Comizzoli P. Biobanking and fertility preservation for rare and endangered species. Anim Reprod. 2017;14(1):30-3. http://dx.doi.org/10.21451/1984-3143-AR889.

Food and Agriculture Organization of United Nations - FAO. Sustainability pathways: we make the path by walking [Internet]. Rome: FAO; 2018 [cited 2021 Mar 21]. Available from: http://www.fao.org/nr/sustainability/home/en/

Frankham R, Bradshaw CJA, Brook BW. Genetics in conservation management: revised recommendations for the 50/500 rules, Red List criteria and population viability analyses. Biol Conserv. 2014;170:56-63. http://dx.doi.org/10.1016/j.biocon.2013.12.036.

Gabora L, Russon A. The evolution of intelligence. In: Sternberg RJ, Kaufman SB, editors. The Cambridge Handbook of Intelligence. Cambridge: Cambridge University Press; 2011. p. 328-50. http://dx.doi.org/10.1017/CBO9780511977244.018

García-Dorado A. On the consequences of ignoring purging on genetic recommendations for minimum viable population rules. Heredity. 2015;115(3):185-7. http://dx.doi.org/10.1038/hdy.2015.28. PMid:25873145.

Gershwin L. Jellyfish: a natural history. Chicago: University of Chicago Press; 2016. http://dx.doi.org/10.7208/chicago/9780226287706.001.0001

Hediger H. Wild animals in captivity. Oxford: Butterworth-Heinemann; 1950.

IUCN Species Survival Commission - IUCN/SSC. Guidelines on the use of Ex situ management for species conservation. Version 2. Gland, Switzerland: IUCN Species Survival Commission; 2014.

Keller L. Inbreeding effects in wild populations. Trends Ecol Evol. 2002;17(5):230-41. http://dx.doi.org/10.1016/S0169-5347(02)02489-8.

Machado LC, Oliveira VC, Paraventi MD, Cardoso RNR, Martins DS, Ambrósio CE. Maintenance of Brazilian Biodiversity by germplasm bank. Pesq Vet Bras. 2016;36(1):62-6. http://dx.doi.org/10.1590/S0100-736X2016000100010.

Machado LC, Roballo KCS, Cury FS, Ambrósio CE. Female reproductive system morphology of crab-eating fox (Cerdocyon thous) and cryopreservation of genetic material for animal germplasm bank enrichment. Anat Histol Embryol. 2017;46(6):539-46. http://dx.doi.org/10.1111/ahe.12306. PMid:28913836.

Mellor DJ, Beausoleil NJ, Littlewood KE, McLean AN, McGreevy PD, Jones B, Wilkins C. The 2020 Five Domains Model: Including Human-Animal Interactions in Assessments of Animal Welfare. Animals (Basel). 2020;10(10):1870. http://dx.doi.org/10.3390/ani10101870. PMid:33066335.

Miranda GM, Coelho ML, de Araujo GR, da Silva MCC, Jorge Neto PN, Csermak AC Jr, et al. Sperm bank of free living jaguars: a tool for the ex situ conservation. In Anais do XXVIII Encontro e XXII Congresso da Associação. Brasileira Veterinários Animais Selvagens; 2019; Florianópolis. Florianópolis: ABRAVAS; 2019. p. 38-41.

Padua S. Afinal, qual a diferença entre conservação e preservação? [Internet]. 2006 [cited 2020 Jul 17]. Available from: https://www.oeco.org.br/colunas/suzana-padua/18246-oeco-15564/

Pinillos RG, Appleby MC, Scott-Park F, Smith CW. One Welfare. Vet Rec. 2015;177(24):629-30. http://dx.doi.org/10.1136/vr.h6830. PMid:26679918.

Pizzutto CS. Avanços na promoção do bem-estar animal nos zoológicos e aquários do Brasil. In: Hartung J, Costa MP, Perez C, editores. O bem-estar animal no Brasil e na Alemanha: Responsabilidade e Sensibilidade. São Paulo: GRAFTEC - Gráfica e Editora Ltda; 2020. p. 138-43.

Praxedes ÉA, Borges AA, Santos MVO, Pereira AF. Use of somatic cell banks in the conservation of wild felids. Zoo Biol. 2018b;37(4):258-63. http://dx.doi.org/10.1002/zoo.21416. PMid:29722907.

Praxedes ÉCG, Peixoto GCX, Silva AM, Silva AR. Reproduction in agouti (Dasyprocta spp.): A review of reproductive physiology for developing assisted reproductive techniques. Anim Reprod. 2018a;15(4):1181-92. http://dx.doi.org/10.21451/1984-3143-AR2018-0058.

Reed DH, O'Grady JJ, Brook BW, Ballou JD, Frankham R. Estimates of minimum viable population sizes for vertebrates and factors influencing those estimates. Biol Conserv. 2003;113(1):23-34. http://dx.doi.org/10.1016/S0006-3207(02)00346-4.

Santos MDCB, Aquino LVC, Nascimento MB, Silva MB, Rodrigues LLV, Praxedes ÉA, Oliveira LRM, Silva HVR, Nunes TGP, Oliveira MF, Pereira AF. Evaluation of different skin regions derived from a postmortem jaguar, Panthera onca (Linnaeus, 1758), after vitrification for development of cryobanks from captive animals. Zoo Biol. 2021. http://dx.doi.org/10.1002/zoo.21605. 
Shaffer ML. Minimum population sizes for species conservation. Bioscience. 1981;31(2):131-4. http://dx.doi.org/10.2307/1308256.

Shaffer ML. Population viability analysis. Conserv Biol. 1990;4(1):39-40. http://dx.doi.org/10.1111/j.15231739.1990.tb00265.x.

Silva HVR, Silva AR, da Silvada LDM, Comizzoli P. Semen cryopreservation and banking for the conservation of neotropical carnivores. Biopreserv Biobank. 2019a;17(2):183-8. http://dx.doi.org/10.1089/bio.2018.0104. PMid:30589562.

Silva MCC, de Araujo GR, Kersul MG, Jorge Neto PN, de Aguiar ACB, Miranda FR, Deco-Souza T. Pharmacological semen collection and cryopreservation of the Giant Anteater (Myrmecophaga tridactyla) in the wild. Rev Bras Reprodução Anim. 2019b;43(2):705.

Silva AMD, Pereira AF, Comizzoli P, Silva AR.Cryopreservation and culture of testicular tissues: an essential tool for biodiversity preservation. Biopreserv Biobank. 2020a;18(3):235-43. http://dx.doi.org/10.1089/bio.2020.0010. PMid:32282240.

Silva HVR, Nunes TGP, Brito BF, Campos LB, Silva AMD, Silva AR, Comizzoli P, Silva LDMD. Influence of different extenders on morphological and functional parameters of frozen-thawed spermatozoa of jaguar (Panthera onca). Cryobiology. 2020b;92:53-61. http://dx.doi.org/10.1016/j.cryobiol.2019.10.195. PMid:31704199.

UN General Assembly. UN General Assembly, “Transforming our world: the 2030 Agenda for Sustainable Development". Nova York: UN General Assembly; 2015. p. 1-35. Resolution adopted by the General Assembly on 25 September 2015.

Waltham NJ, Elliott M, Lee SY, Lovelock C, Duarte CM, Buelow C, Simenstad C, Nagelkerken I, Claassens L, Wen CK-C, Barletta M, Connolly RM, Gillies C, Mitsch WJ, Ogburn MB, Purandare J, Possingham H, Sheaves M. UN Decade on Ecosystem Restoration 2021-2030: what chance for success in restoring coastal ecosystems? Front Mar Sci. 2020;2020(7):1-5. http://dx.doi.org/10.3389/fmars.2020.00071.

\section{Author contributions}

CSP: Conceptualization, Writing - original draft, Writing - review \& editing; HC: Conceptualization, Writing - original draft, Writing - review \& editing; PNJN: Conceptualization, Writing - original draft, Writing - review \& editing, Supervision. 